\title{
Hungarian Turanism. From the Birth of the Ideology to Modernity - an Outline of the Problem
}

\author{
Węgierski turanizm. Od narodzin ideologii do czasów współczesnych - \\ zarys problematyki
}

\section{- Abstrakt •}

Artykuł stanowi zarys problematyki węgierskiego turanizmu - fenomenu ideologicznego w Europie Środkowej. Odgrywał on relatywnie ważną rolę na Węgrzech w pierwszej połowie XX w., obecnie zaś następuje jego odrodzenie. Turanizm jest bardzo ważną częścią ideologii promowanej przez partię Jobbik (Ruch na rzecz Lepszych Węgier). Sam termin „Turanizm” pochodzi od słowa Turán, prawdopodobnie wywodzącego się z języka staroperskiego. Używane było w celu określenia Azji Środkowej zamieszkanej przez plemiona koczownicze. Według ideologii turańskiej Węgrzy są spokrewnieni z ludami ałtajskimi, takimi jak: Turcy, Azerowie, Tatarzy, Kazachowie, Mongołowie, a nawet Tybetańczycy oraz Japończycy. Wielu węgierskich badaczy i odkrywców odwiedziło Azję Środkową w celu odnalezienia ludów spokrewnionych z Węgrami. Należy podkreślić, że współczesny turanizm węgierski, zwłaszcza reprezentowany przez Jobbik, zajmuje zdecydowanie antyzachodnie stanowisko. Jobbik jest bardzo krytycznie nastawiony wobec międzynarodowej polityki Unii Europejskiej oraz Stanów Zjednoczonych, zaś Wę-

\section{- Abstract •}

This article is an outline of Hungarian Turanism, Central European ideological phenomenon. The ideology was relatively important in Hungary during the first half of the $20^{\text {th }}$ century and is currently undergoing a revival in the country. Turanism is a very important part of the ideology promoted by the Jobbik party (Movement for a Better Hungary). The term "Turanism" is derived from Turán, a word most likely of OldPersian origin, once used to describe the lands of Central Asia inhabited by nomadic tribes. According to the ideology of Turanism, Hungarians are related to Altaic peoples, such as Turks, Azeris, Tatars, Kazakhs, Mongols, and even Tibetans and Japanese. Many Hungarian researchers and explorers travelled to Central Asia in order to find peoples related to Hungarians. It is noteworthy to point out that modern Hungarian Turanism, particularly as it is represented by Jobbik, displays strong anti-Western attitudes. Jobbik is very critical of the international policy of the European Union and the United States, and considers Hungary to be a victim of the West. What is more, Jobbik strongly criticises globalism, liberalism and anti-traditionalism, 
gry uważa za ofiarę Zachodu. Co więcej, Jobbik stanowczo krytykuje globalizm, liberalizm oraz antytradycjonalizm, co uważa za cechy współczesnych społeczeństw zachodnich. Z tego powodu „Zwrot na Wschód” Jobbiku wydaje się być jednocześnie odwrotem od Zachodu.

Słowa kluczowe: Jobbik, nacjonalizm, nacjonalizm węgierski, turanizm, Węgry which it considers to be features of modern Western societies. Because of this, Jobbik's "Eastern Turn" appears to be a turn away from the West.

Keywords: Jobbik, nationalism, Hungarian nationalism, Turanism, Hungary

\section{Introduction}

Hungarian Turanism should be considered a Central European phenomenon. It was an ideology important in Hungary during the first half of the $20^{\text {th }}$ century and based on old traditions and the belief that Hungarians are successors to the Huns. Therefore, in Turanian ideology Hungarians are recognised as being related to Altaic peoples, which include Turks, Azeris, Tatars, Kazakhs, Mongols, and even Tibetans and the Japanese. This belief was the reason for which many Hungarian researchers and explorers have decided to visit Central Asia. Their goal was to find people related to Hungarians, as well descendants of ancient Hungarians. Today, this historical ideology is undergoing a revival in Hungary. Turanism is a very important part of the ideology promoted by Jobbik Magyarországért Mozgalom (Movement for a Better Hungary), one of Hungary's major political parties.

There are few works of research on Hungarian Turanism, particularly about its contemporary incarnation. The most important work has been written in English by an American historian Joseph Kessler in 1967 (1967). However, it was only a $\mathrm{PhD}$ dissertation and has never been published as a book. Naturally, Kessler was only concerned with Turanism up to year 1945. Interestingly, neither are there many modern research works on the subject written in Hungary. It is of course easy to find many publications presenting Turanist views, which can be considered as sources for research into the subject. Nevertheless, a noteworthy example to mention is the book by László Szendrei, a Hungarian historian, $A$ turanizmus (Turanism). In this very compact book, Szendrei focuses mostly on defining and explaining the notion of Turanism, although some short texts by pre-war Turanists are available as well (2010). The purpose of this article is to serve as an introduction to the topic of Hungarian Turanism, which is the subject of the author's $\mathrm{PhD}$ dissertation. The first part will present the historical conditions in which Turanism emerged and the ideology's beginnings. The second part will cover the development of the Turanist movement in Hungary up until World War II. The 
third part of the article will describe the modern Turanist movement in Hungary, while in the fourth and final part will present Turanism as it is employed in the discourse of Jobbik.

\section{Historical Conditioning of Turanism and the Origins of Its Ideology}

Firstly, we should define the meaning of the term "Turanism". It is derived from Turan, a word which is probably of Old-Persian origin and was used to describe the lands in Central Asia inhabited by nomadic tribes. These lands were located to the north of what is today Iran (The Editors of Encyclopedia Britannica, 1998). We can read about Turan in the Avesta, a collection of religious texts of Zoroastrianism. On the other hand, in Shahnameh (The Book of Kings), the national epic of Iran written by Persian poet Ferdowsi, Turanians are nomads and enemies of Iran. The conflict between Iran and Turán is symbolic: it is the struggle between the forces of light and of darkness (Szendrei, 2010). According to the orientalist Gyula Germanus, it was "an ancient Iranian myth, which was naturally a reflection of an anthropologic and geographic antagonism as a divine struggle between light and darkness, good and evil" (Szendrei, 2010). We cannot precisely determine where Turán was located, however it was presumably to the north of Iran, between the Caspian Sea and the Kirghiz Steppe. The first to employ the term Turan in the Hungarian literature was Ferenc Pulszky, who used it in 1839 as a geographic concept (Szendrei, 2010). However in 1895 Géza Nagy wrote that "Turanian" is synonymous with "Ural-Altaic" and that Turanians should be considered Central Asian nomads: Huns, Cumans, Hungarians, Tatars, Turks, Kyrgyz, etc. (Szendrei, 2010). In this case, the term is used in an anthropologic meaning.

Turanism is variously defined either positively or negatively. Worth mentioning are the views of Árpád Zempleni, a propagator of Turanist ideology. In 1917, he wrote that Turanism is "a certain effort towards rapprochement between Uralic, Altaic, Finnic, and Mongolic peoples. It is self-defense against «oppressive and assimilating Aryan efforts» and the establishment of public education, as well as economic and political co-operation" (Szendrei, 2010). In 1925, a concise definition of Turanism appeared in Révai nagy lexikon: "it is Turanian movement, peoples, and states, and the co-operation in the fields of culture, economy, and politics, as well progress in the matters of creative output and development" (Szendrei, 2010). It is also important to mention the critical perception of Turanism. The aforementioned Gyula Germanus was its fierce critic. In his opinion, the goal of Turanism 
was not to provide reliable knowledge, but to foster "an imaginary, fictitious idea of kinship" in order to reap political benefits (Szendrei, 2010). Zoltán Szász agreed with this view and wrote that Turanism is "just a dream, without any scientific base" (Szendrei, 2010). Another critic, Miklós Kállay, wrote in 1927 that Turanism "is not a new idea, not a new aspiration. In Germany, it spreads under the name of Wotanism" (Szendrei, 2010). He thereby compared Turanism to German neo-paganism.

\section{Turanist Movement in Hungary until World War II}

Expeditions motivated by the desire to find the Hungarians' ancestral homeland were organised as early as in the Middle Ages and many scientists identified Hungarians (Magyars) with Turks or Huns. In the $14^{\text {th }}$ century, Elias Hungarus and Gregorius de Hungaria were looking for ancient Hungarians' heritage in Mongolic tribes. In the $18^{\text {th }}$ century, Sámuel Hatvani Turkol, a Hungarian working for Tsar Peter the Great, declared that he had visited villages in Crimea, where the inhabitants spoke Hungarian ("Finn-ugor" tanok..., 2009). The importance of ethnic matters in the subsequent century induced many researchers and explorers to look for peoples related to Hungarians. János Orlay, Gergely Nagylaki Jakcsics and János Besse were searching in the regions of the Eurasian Steppe and the Caucasus. Sándor Körösi Csoma (1784-1842), who visited Tibet, is widely believed to be the most important of those researchers (Sándor Körösi...). His successor was Ármin Vámbéry (1832-1913), who suggested that Hungarian was a language related to Turkish. In 1882, he published his seminal work $A$ magyarok eredete (The origins of Hungarians), which provoked a lot of controversy among scientists (Vámbéry, 1882). In 1895, Vámbéry amended his views and published further studies about the ethnogenesis of Hungarians. He decided to expand his thesis, from Turkic to Ural-Altaic. Thus, he suggested that Hungarians are related to many peoples belonging to a large Ural-Altaic language family. At the same time, he stated that the ethnogenesis of Hungarians was a long-term process of 1,000 years (400-1.400 C.E.), spanning from the Hunnic to the Mongol invasion (Kessler, 1967). According to that theory, Hungarians are a synthesis of different Ural-Altaic peoples. Vámbéry's thesis generated very fierce debates that came to be known as the Ugric-Turkish War (Akçalı, Korkut, 2012). Scientific circles in Hungary separated into two competitive and hostile camps: followers of the UralAltaic and of the Finno-Ugric theories. Vámbéry's main opponent was the Hesseborn József Budenz (1836-1892), who came to Hungary to research Hungarian 
language. In 1881, he published Magyar-ugor összehasonlitó szótár (The Comparative Hungarian-Ugric Dictionary; Budenz, 1881). Budenz was certain that there was a connection between Hungarian and the Finno-Ugric languages.

The Ural-Altaic theory enabled the emergence of the Turanist movement. In 1910, a group of prominent scientists, nobles and politicians established the Turanian Society (Turáni Társaság). Its members included many prominent personages from the Hungarian elite, such as Count Pál Teleki, the famous geographer and later Prime Minister of Hungary (Kessler, 1967). It is also important to mention such persons as museologist Alajos Paikert, geographer and writer Jenő Cholnoky, as well as historian Sándor Márki (Ablonczy, 2005). Their main goal was to study and promote links between Ural-Altaic peoples and Hungarians. Teleki became the first president of the Turanian Society. The objective of the new organisation was not to build a mass-movement, but to bring together the representatives of Hungarian elite and promote Turanism among them, which eventually proved to be partly successful (Kessler, 1967). In 1913, the Turanian first published its own journal Turán, with articles written in various languages and presenting expeditions and studies. In the first issue of Turán, Paikert stated that there were many areas of Asia that were unspoilt, while Hungary needed to expand economically. Those lands were waiting for Hungarian colonisation and the local inhabitants were considered by Paikert to be as friendly towards Hungarians as brotherly peoples (Paikert, 1913).

Turanists received support from the Hungarian government in 1915, when Turkey and Bulgaria decided to join the Central Powers. The Slavic Serbia was defeated and Russia suffered immense losses. It appeared that the Central Powers would quickly win the war; this made Turanism politically useful, also due to its anti-Pan-Slavic attitude. There were plans to create independent states for Turanian peoples inhabiting Russia, like Crimean Tatars, Kazan Tatars, or Azeris. Turanists were also counting on a political rapprochement between Hungary and Turkey (Kessler, 1967). Meanwhile, in May 1916, the name of the Turanian Society was changed to Hungarian Eastern Cultural Centre (Magyar Keleti Kultúrközpont) and during the years 1917-1918 it was formally identified by this name. In November 1916, Count Teleki resigned from presidency of the society. During the war, the organisation was supporting students and prisoners of war of Altaic origin. It seemed to be an excellent opportunity for establishing lasting links with the future elites of Turanian nations (Kessler, 1967). However, the Central Powers were defeated by the Allied Powers and Hungary lost the vast majority of its territories in the Treaty of Trianon (1920), although it did become a fully independent state. Obviously, such a development was a disappointment for Tu- 
ranists. During the communist terror of Béla Kun's government, the society was formally disbanded, the reason being that it promoted an ideology and program which were "utterly obsolete and contrary to the spirit of the age". After the establishment of Admiral Miklós Horthy's regime, the Turanist movement fragmented into several groups (Kessler, 1967). The moderate fraction, led by Count Teleki, left the society and established academic organization called the Körösi Csoma Society (Körösi Csoma Társaság). ${ }^{1}$ Simultaneously, the most radical group under the leadership of Jenő Cholnoky established their own organisation, the Turanist Union of Hungary (Magyarországi Turán Szövetség), which was strongly antiWestern in its views. Meanwhile, the publication of Turán was resumed by the Turanian Society under the leadership of Gyula Pekár. During the interwar period, the organisation received some support from the government; however, it was not financially stable and was forced to rely on donations from private individuals. One of its most important patrons was Pekár, who led the Turanian Society until his death in 1937. He was influential and wealthy, with numerous good connections among the Hungarian elites. According to Joseph A. Kessler "It might even be said that until his death in 1937, the Turanian Society was, to some extent, the personal organization of Gyula Pekar" (Kessler, 1967).

The aforementioned Turanist Union of Hungary, led by Cholnoky, was very radical, formerly a very active member of the Turanian Society. Many prominent persons joined the Society's ranks, such as Gyula Mészáros, Lajos Sassi-Nagy, Sándor Márki, or Benedek Baráthosi-Balogh (Kessler, 1967). The structure of new organisation was very interesting as well: Cholnoky was titled "The Grand Leader" (Nagy Vezér) and his deputies were called "Leaders" (Vezér). The Turanist Union of Hungary was composed of basic units called "Clans" (Nemzetség) and "Tribes" (Törzs). The organisation was not focused solely on the Turanian issue, but was also strongly anti-aristocratic, anti-capitalist, anti-clerical, anti-modernist, anti-Western, anti-German and anti-Slavic. The organisation was less focused on academic work and was instead trying to convert Turanism into a popular ideology. Although the Turanian Society and Turanist Union of Hungary were competing with one another, it is hard to speak of hostility. Sometimes representatives of both organisations were participating in joint undertakings. For example, in 1924, Gyula Mezey (Turanian Society) and Antal Szentgaly (Turanist Union of Hungary) became co-chairmen of the newly established Hungarian-Japanese Friendship Society (Magyar-Japán Baráti Társaság; Kessler, 1967). Nevertheless,

1 The Körösi Csoma Society continues to exist to this day and its focus are Asian studies. See: A Körösi Csoma Társaság honlapja. Retrieved from: http://www.kcst.hu/. 
the Turanian Society played a much more important role in the interwar period and was able to gain support of prominent persons belonging to the political elite of Hungary. Honourable members of the Society included such important figures as Gyula Gömbös (Prime Minister of Hungary in 1932-1936) or Bálint Hóman. Meanwhile, the death of Pekár in 1937 has temporarily disrupted the work of the Society. At the same time in 1930s, some much more radical Turanist group emerged, like the neo-pagan Turanian Monotheists (Turáni Egyistenhívők), trying to recreate the religion of Proto-Hungarians (Kessler, 1967). Some organisations were definitely inspired by German National Socialism, however the leadership of Turanist Union of Hungary criticised the Arrow Cross Party (Nyilaskeresztes Párt) of Ferenc Szálasi for being "pro-Aryan” (pro-German) (Turmezei, 1935). Meanwhile, the neo-pagan trends were unable to gain support of Horthy's regime, which was officially founded on Christian values. Turanists hoped that the coming World War II would lead to a revision of the Treaty of Trianon. During the war, the Turanian Society again became more active under the leadership of Cholnoky, the former "Great Leader" of Turanist Union of Hungary. Many people decided to join the organisation; for example, in 1944 the Turanian Society had 582 members in Budapest alone (Kessler, 1967). However, World War II was another disappointment for Hungarian Turanists. After a brief but brutal rule of the Arrow Cross Party, Hungary became a communist state with occupied by Soviet troops. Any activity of an official Turanist movement in Hungary became almost impossible until 1989.

\section{Turanism after 1989}

The fall of the Iron Curtain allowed for re-emergence of Turanist movement, although no organisation as influential as the pre-war Turanian Society exists. The largest and the most important group appears to be the Hungarian-Turan Fund (Magyar-Turán Alapítvány) under the leadership of András Zsolt Bíró (Information. Kurultaj...). It is noteworthy to point out that the modern Turanist movement has different opportunities than those available to its predecessors. First of all, the Internet is a very useful tool in promoting Turanism. Thanks to the Internet, one can obtain knowledge about Turanists and their vision of history, but it is also possible to buy Turanist clothes, caps, pendants, mugs, arches and knives of ancient warriors, as well as many other gadgets (Turánia...). Turanist themes are also present in songs of bands representing the Hungarian "National Rock" (Nemzeti Rock) genre. For example, the famous Hungarian band Kárpátia has 
written a song titled Turul, about the bird from Hungarian mythology: "Come, come, Turul bird, Hungary has lost its way, sweet Turul bird, the Fatherland awaits your return" (Kárpátia - Turul...). Kárpátia also recorded a song dedicated to Cumans, the nomadic Turkic people who settled in Hungary in the Middle Ages. Interestingly, the song is written in the ancient Cuman language (Kárpátia - Kun miatyánk...). It is beyond any doubt that Turanism became a part of Hungarian mass culture, although mostly among nationalists.

The previously Hungarian-Turan Fund was established in 2009. The members of the organisation include many scientists as well as social activists. They are interested in research work about peoples recognised as Turanian, their lifestyle and mutual links. A very important objective of the organisation is also the promotion of Turanism. Hungarian-Turan Fund organises numerous meetings, lecturers and performances of Turanian folk dances and re-enactors of Turanian warriors (Magyar-Turán Alapitvány..., 2015). Its leader, anthropologist András Zsolt Bíró, stated in 2006 that DNA samples show a relationship between the Kazakh tribe of Madjars and the Hungarians (Magyars), meaning they have more than just the name is common. Bíró published his research paper and visited Kazakhstan. He decided to organize the Kurultaj Festival, which is described on the event's website in English as "Kurultaj - tribal assembly of the Hun-Turkic nations, celebration of the preservation of the ancient traditions" (Information. Kurultaj...). In the some Altaic languages the word Kurultaj means "meeting of the tribes", something which occurs among many nomadic peoples. According to the organisers, such meetings are also very important for Hungarian culture and mentioned in Hungarian literature. The Kurultaj Festival is held in summer, in the village of Bugac, $160 \mathrm{~km}$ south of Budapest, close to Kiskunság National Park. Before every Kurultaj organisers construct a large nomadic village with innumerable Turanian tents (yurts); there are also special corrals and stables. During the event, guests can see performances by warrior re-enactors, folk dances, archaeological exhibitions, or listen to numerous lectures. In 2012, a decision was made that the event will be held once every two years and that representatives of all Turanian nations will be invited (Information. Kurultaj...). The organisation of the Kurultaj received Jobbik's acclaim (Fidesz-MSZP összefogás..., 2013). It is also important to mention that Hungarian-Turan Fund develops international contacts with representatives of nations recognised as Turanian. For example in October 2015, Bíró was a guest of honour of the Turan Unity Movement (Ahde Vefa Turan Birliği) in the Turkish city of Konya. His lecture about common historical connections met with big interest (Turán konferencia..., 2015). Furthermore, in June of 2016, Bíró visited Kyrgyzstan, where he had the opportunity to meet with representatives of the gov- 
ernment (Kirgiz-magyar együttmüködés..., 2016). Leaders of the Fund, including Bíró, where also guests in Turkmenistan (Magyarország elöször..., 2015) and sent delegation to the congress of Macedonian Turks (Magyar diszvendégek..., 2015).

\section{Turanism in the Discourse of Jobbik}

A very important contribution to promotion of Turanism has been made by the previously mentioned Jobbik party. It was established as a political party in October 2003 and was based on the Right-Wing Youth Association (Jobboldali Ifjúsági Közösség), which was a group of university students with nationalist and right-wing views (A kezdetek:...). The first success of the party came in 2009, when Jobbik won 3 seats in the European Parliament. However, in the Hungarian parliamentary elections in April 2014, the party received over $20 \%$ of votes, which was the biggest success in Jobbik's history (Országgyülési képviselök...). The English-language version of Jobbik's website states that "The Jobbik - Movement for a Better Hungary is a principled, conservative and radically patriotic Christian party. Its fundamental purpose is protecting Hungarian values and interests" (A Short Summary...). As we can see from that quote, the party does not consider itself nationalist but "conservative" or "radically patriotic", with its fundamental purpose being the protection of Hungarian values and interests. This very moderate description is completely different from the way Jobbik is presented in the international press, especially with liberal and left-wing leanings. The party is usually described as "neo-nazi" (Rev, 2015), "far-right", "populist", (Aisch, Pearce, Rousseau, 2016), "neo-fascist" (Chomsky, 2011) and so on. However in 2014, the Supreme Court of Hungary ruled that Jobbik cannot be deemed "far-right", which term was used by ATV, a Hungarian commercial television channel, in a 2012 newscast. The party also rejects such labels (Zalan, 2014). What is more, during the Party's 2016 congress, Jobbik Gábor Vona, president of Jobbik, declared that they want to be a "national people's party" (Nemzeti néppárt...). This article will not discuss whether or not Jobbik is "far-right" or "populist", as this is not its purpose, but the focus will rather be on Turanism in the discourse of Jobbik.

It is also important to emphasise Jobbik's general views on foreign policy. Jobbik is considered a revisionist party, which disagrees with the provisions of the Treaty of Trianon (1920), according to which Hungary lost a vast majority of territories. Many Hungarians have still not come to terms with that. Jobbik has criticised the treaty a number of times. Gábor Vona condemned Trianon during 
his interview for the Austrian Zur Zeit weekly, saying that "In my interpretation a treaty is always the result of negotiations. What happened in the Trianon Palace in Versaille after the First World War was a dictate, whereby the enemies of Hungary decided the fate of our country on the basis of lies, manipulated figures and false reports. [...] For Hungarians Trianon is the synonym for an attempt of liquidating the Hungarian nation" (Gabor Vona: Europe..., 2010).

The Treaty of Trianon is one of the reasons why Jobbik displays a very negative attitude towards the West. What is more, the party openly criticises the international policy of the European Union, United States, NATO and Israel (Külügyi program...). Jobbik also condemns the Euro-Atlantic co-operation, perceiving it as a vehicle for the United States to secure its interests. Therefore, the party calls for the replacement of Euro-Atlantic co-operation with Euro-Asiatic co-operation. Obviously, that means that Jobbik considers Russia as very desirable ally for Hungary, putting aside the historical animosity towards Moscow (Габор Вона:...). Jobbik's politicians express respect for the geopolitical ideas of Alexandr Dugin, the main ideologist of Eurasianism and former advisor to Vladimir Putin. Furthermore, Dugin and Vona met in Moscow, where they discussed common goals (Vona Gábor a..., 2013). According to Vona, Hungarians, Turks and Russians are the three nations preserving "universal human traditions" (Vona Gábor: az..., 2013). What is more, these nations are, due to their history, fate and disposition, European and Asian at the same time. Therefore, Hungarians, Turks and Russians should create a "Eurasian alternative" to the Euro-Atlantic co-operation (Vona Gábor: az..., 2013). On a side note, it is noteworthy to point out that Jobbik declares its intention to maintain good relations between Hungary and Germany, as well as the hope for the development of Central European co-operation. Poland and Croatia are considered by Jobbik to be possible allies (Külügyi program...).

Turanism is undoubtedly a very important part of Jobbik's activity, which becomes obvious if one analyses the party's vision of Hungarian foreign policy, as well as the discourse of Jobbik about the international politics. The party remains consistent in supporting states and nations recognised as Turanian (Azerbaijan in conflict against Armenia, Turkish Cypriots against Greeks, etc.). What is very interesting, Islam, the religion professed by a large part of nations Turanists consider to be related (e.g. Turks, Azeris and Kazakhs), is not considered an obstacle. Turanism is to play an important part not only in Hungarian foreign policy, but also in the reconstruction of Hungarians' national identity. Whenever Jobbik's politicians speak out about Hungarian origins and affiliation, they readily support the theory that Hungarians are one of the Turanian peoples (Fidesz-MSZP összefogás..., 2013). 
Jobbik's views on Islam significantly differ from those of most parties in Europe that are recognised as nationalist, which consider Muslim people as a serious threat to the safety and the identity of Europe. After Anders Breivik's terrorist attack in Norway, Jobbik's MP Márton Gyöngyösi published a statement on the party's English-language website, criticising Breivik's ideology. The title of the statements is: A Hungarian party advocating "Eastern Turn" and return to Asian roots cannot be allied with Western anti-Islamic radicals! (Gyöngyösi, 2011). Gyöngyösi stated that Jobbik was criticised by international press in connection with the attacks, but that his party represents a "unique position" when it comes to their foreign policy strategy. "The most recent accusations of the Western press against Jobbik was on the apropos of the brutal Breivik-massacre in Norway, hinting at a mysterious connection between Breivik's ideology and that of Jobbik. These lies were based on the single fact that Breivik mentioned in his 1,500 page diary radical movements in Hungary that he knew of - amongst them Jobbik. The media was silent about the fact that Breivik in reality heavily criticized Jobbik for not being anti-Islamic", announced Gyöngyösi (2011). Therefore, he suggests that Jobbik is not "anti-Islamic" or "xenophobic", as opposed to many movements in Western Europe. He emphasised that Jobbik has for years been implementing the "Eastern Turn" postulated in the party's program. Jobbik's MP tries to convince that Hungarians are the only one European nation with Asiatic roots, and that therefore brotherly relations with such countries as Turkey or Azerbaijan are very important (Gyöngyösi, 2011).

It is also necessary to mention the opinions held by Gábor Vona. The president of Jobbik has visited Turkey and declared that it is necessary to cooperate with Muslims. He emphasised that Turkey is a prospering country with a population of 80 million and has the second largest army within NATO structures. He also argues that that Turkish people love Hungarians, despite of struggles in the history: "at school, they teach children that Hungarians and Turks are relatives" (The Background..., 2013). Therefore, according to Vona, it is beneficial for Hungary if Turks consider Hungarians their brothers. According to him, the real problem is not in the differences between various religions or cultures, but between the nations trying to preserve their own traditions and the "anti-traditional, global liberalism". What is more, Vona believes that the Muslim world continues to resist the world dominated by the United States. President of Jobbik encourages Christians, Muslims and believers of other religions to join together in a fight against global liberalism. He stated that countries Hungary now calls allies are in fact destroying the economy of Hungary, exploiting Hungarians as cheap labour, forcing them to fight in pointless wars and disrespect Hungarians' national traditions. However, Vona declares that 
he does not support Islam at the expense of Christianity: "What I said was that the Islam civilization protects its own tradition more strongly than Christianity does. [...] As a Roman Catholic, I have pointed out several times that the church should not be content with just being a social institution and letting lies exercise their destructive effects. They should undertake the ideological fight as well. So I was not speaking out against Christianity, I was speaking out for it" (The Background..., 2013). Vona pointed out that as a president of Jobbik, "a party considered aggressive and xenophobic", he encourages dialogue between cultures and religions. At the same time he condemns both terrorism and "the wars of invasion marching under the pretentious banner of anti-terrorism" (The Background..., 2013).

Politicians of Jobbik not only speak about Turanism, but they also travel to countries considered Turanian. In October 2013, Vona paid a visit in Turkey, where he met with students of several Turkish universities and delivered lectures (Vona Gábor: az..., 2013). He was talking about Hungarian-Turkish kinship, common ancestors and about a need for co-operation. In his opinion, religious differences should not be an obstacle in developing mutual relations in many fields. What is more, he suggested that the mission of Turanism could be to build bridges between the West and the East, between Islam and Christianity. In his opinion, Hungarians and Turks should begin, because they are related by blood (Vona Gábor: az..., 2013). Currently, Jobbik is also trying to develop relations with other countries recognised as Turanian. As it has already been mentioned, Jobbik supports Azerbaijan in its conflict against Armenia over Nagorno-Karabakh. In February 2013, an article titled Jobbik expresses solidarity with brotherly Azeri nation was released on Jobbik's English-language website (Jobbik Expresses..., 2013). The operations of Armenian forces were described by Jobbik as a "military aggression". Jobbik blamed Armenians for committing numerous crimes against civilians, like driving away 250 thousand Azeri people away from their homeland in Armenia, and for other actions that can be described as ethnic cleansing. Jobbik decided to express solidarity with the Azeri nation on account of the $21^{\text {st }}$ anniversary of Khojaly Massacre (1992), perpetrated during the Nagorno-Karabakh War. According to Jobbik, Armenia still occupies almost one fifth of Azerbaijan's territory. The party also emphasises that it supports Azerbaijan to express its solidarity with a Turanian kinsfolk (Jobbik Expresses..., 2013).

As a matter of fact, it is hard to find any Jobbik politician condemning the Armenian Genocide, which still presents an obstacle in Turkish-Armenian relations. Jobbik also promoted twin-city agreement between the cities of Gyöngyös and Shusha, which "belongs to Azerbaijan but has been occupied by Armenia since 1992" (Horváth, 2013). On that occasion Jobbik has again condemned the Arme- 
nian forces for the Nagorno-Karabakh conflict and carrying out ethnic cleansing. Gábor Vona expressed appreciation for Azerbaijan's development and called the twinning an example of fraternity between Turanian nations (Horváth, 2013). Just one month later, another Hungarian town, Tiszavasvári, also signed a similar agreement with Aghdam, another city in Azerbaijan currently under control of Armenian forces. It is noteworthy to say that it was signed by Tiszavasvári's mayor Erik Fülöp, a politician belonging to Jobbik, who declared the support of his city for Azerbaijan and Azeri people (Rajabova, 2013).

\section{Conclusions}

Hungarian Turanism can be considered as unique ideology in the Central Europe, as Hungarian language is very distinct from the Indo-European languages spoken by all of Hungary's neighbours, most of whom are Slavic. However, pan-ideologies are nothing new if we remember about Pan-Slavism or Pan-Germanism. The possibility of forging stronger relationship with peoples recognised as related seems to offer new opportunities. The uniqueness of Hungarian Turanism consists in looking for special relations with non-European, mostly Asian, peoples. What is more, many of those Altaic peoples (which are recognised as Turanian) are not Christian, but followers of Islam, which could appear to be an obstacle. For example, Pan-Slavism was rooted solely in Orthodox faith, considered to be the "true religion" of Slavs, which alienated some mostly Catholic nations, such as Poles and Croats, from the idea of Pan-Slavism. However in case of Turanism, religion does not seem to pose an issue. It may be surprising for many that Jobbik, often considered to be "far-right" or "xenophobic", promotes the ideology of Turanism and calls for reconciliation between Christians and Muslims.

When discussing Hungarian Turanism, especially as represented by Jobbik, we have to also remain conscious of its anti-Western attitude. Jobbik is very critical of the international policy of the European Union or the United States. Hungary is considered a victim of Western policy due to the Treaty of Trianon. Politicians of Jobbik also strongly criticise globalism, liberalism and anti-traditionalism, which they consider to be important components of modern Western societies. Therefore, the "Eastern Turn" seems to be a turn away from the West. Considering the crisis now experienced by the West, we can infer that Turanism may become an ideology more popular in Hungary. On the other hand, the migrant crisis in Europe may prove an obstacle for Hungarian Turanists in their attempts to foster better relationships with some Muslim nations considered to be Turanian. 


\section{References:}

Ablonczy, B. (2005). Teleki Pál. Budapest: Osiris.

Aisch, G., Pearce, P., Rousseau, B. (2016). How Far Is Europe Swinging to the Right. Derived from: http://www.nytimes.com/interactive/2016/05/22/world/europe/europeright-wing-austria-hungary.html?_r=0.

Akçalı, E., Korkut, U. (2012). Geographical Metanarratives in East-Central Europe: Neo-Turanism in Hungary. Eurasian Geography and Economics, 53 (5), 596-614.A kezdetek: A Jobbik megalakulása. Derived from: https://jobbik.hu/jobbikrol/kezdetekjobbik-megalakulasa.

A Körösi Csoma Társaság honlapja. Derived from: http://www.kcst.hu/.

A Short Summary About Jobbik. (2010). Derived from: http://jobbik.com/short_summary_about_jobbik.

Budenz, J. (1881). Magyar-ugor összehasonlitó szótár. Budapest: Magyar Tudományos Akademia.

Chomsky, N. (2011). Is the World Too Big to Fail?. Derived from: http://www.salon. com/2011/04/21/global_empire_united_states_iraq_noam_chomsky/.

Fidesz-MSZP összefogás a turáni népek ellen. (2013). Derived from: http://alfahir.hu/ node/121861.

"Finn-ugor" tanok és a madjar Belsö-Ázsia. (2009). Derived from: http://kurultaj. hu/2009/10/finn-ugor-tanok-es-a-madjar-belso-azsia/.

Gabor Vona: Europe Kept Silent - Intervew. (2010). Derived from: http://www.jobbik. com/gabor_vona_europe_kept_silent_-_interview.

Gyöngyösi, M. (2011). Statement of Jobbik Against Accusations re Breivik-Case. (2011). Derived from: http://jobbik.com/statement_jobbik_against_accusations_re_breivikcase.

Horváth, Á. (2013). "Mindkét országnak kötelessége küzdeni területeiért" - Gyöngyös azeri testvérvárosa. Derived from: http://alfahir.hu/node/123662.

Information. Kurultaj - tribal assembly of the Hun-Turkic nations, celebration of the preservation of the ancient traditions. Derived from: http://kurultaj.hu/english/.

Jobbik Expresses Solidarity with Brotherly Azeri Nation. (2013). Derived from: http://jobbik.com/jobbik_expresses_solidarity_brotherly_azeri_nation.

Kárpátia - Kun miatyánk. Derived from: http://www.zeneszoveg.hu/dalszoveg/50449/ karpatia-/kun-miatyank-zeneszoveg.html.

Kárpátia - Turul. Derived from: http://www.zeneszoveg.hu/dalszoveg/56666/karpatia-/ turul-zeneszoveg.html.

Kessler, J. (1967). Turanism and Pan-Turanism in Hungary: 1890-1945. (Ph.D. thesis). Berkeley: University of California.

Kirgiz-magyar együttmüködés a hagyományörzésben. (2016). Derived from: http://kurultaj. hu/2016/06/kirgiz-magyar-egyuttmukodes-a-hagyomanyorzesben/.

Külügyi program. Derived from: https://jobbik.hu/programunk/kulpolitika.

Magyar diszvendégek Macedóniában, a Balkáni Törökök Nagygyülésén. (2015). Derived from: http://kurultaj.hu/2015/03/magyar-diszvendegek-macedoniaban-a-balkanitorokok-nagygyulesen/. 
Magyarország elöször vett részt a Türk Világ Kulturális Fövárosának díszünnepségén. (2015). Derived from: http://kurultaj.hu/2015/01/magyarorszag-eloszor-vett-reszt-a-turk-vilag-kulturalis-fovarosanak-diszunnepsegen/.

Magyar-Turán Alapitvány - életképek. (2015). Derived from: http://kurultaj.hu/2015/11/ magyar-turan-alapitvany-eletkepek/.

Nemzeti néppárt. (2016). Derived from: https://jobbik.hu/hireink/nemzeti-neppart. Országgyülési képviselök választása. (2014). Derived from: http://valasztas.hu/hu/ ogyv2014/861/861_0_index.html.

Paikert, A. (1913). Ázsia jövője. Turán, 1(1), 7-14.

Phillips, L. A Far-Right for the Facebook Generation: The Rise and Rise of Jobbik. (2010). Derived from: https://euobserver.com/political/29866.

Rajabova, S. (2013). Azerbaijani Occupied Town Twinned with Hungary's Tiszavasvari. Derived from: http://www.azernews.az/azerbaijan/55146.html.

Rev, I. (2015). Hungary's Politics of Hate. Derived from: http://www.nytimes.com/ 2015/09/26/opinion/hungarys-politics-of-hate.html.

Sándor Körösi Csoma élete. Derived from: http://csoma.mtak.hu/hu/csoma-elete.htm.

Szendrei, L. (2010). A turanizmus: definíciók és értelmezések 1910-töl a II. Világháborúig. Máriabesnyő-Gödöllö: Attraktor.The Background of Real Conflict in the World. (2013). Derived from: http://jobbik.com/background_real_conflict_world.

The Editors of Encyclopedia Britannica. (1998). Pan-Turanianism. Derived from: http:// www.britannica.com/EBchecked/topic/440695/Pan-Turanianism.

Turánia. Derived from: http://www.turania.hu/catalog/index.php.

Turán konferencia Konya városában. (2015). Derived from: http://kurultaj.hu/2015/10/ turan-konferencia-konya-varosaban/.

Turmezei, L. (1935). A turáni sajtóiroda és története. Budapest: Magyarországi Turánok Baráti Köre.

Vámbéry, A. (1882). A magyarok eredete: ethnologiai tanulmány. Budapest: A Magyar Tudományos Akadémia Könyvkiadó Hivatala.

Vona Gábor a Lomonoszov Egyetemen tartott elöadást. (2013). Derived from: https://jobbik. hu/hireink/vona-gabor-lomonoszov-egyetemen-tartott-eloadast.

Vona Gábor: az eurázsiai jövő alapja a tradíció. (2013). Derived from: http://alfahir.hu/ vona_gabor_az_eurazsiai_jovo_alapja_a_tradicio.

Zalan, E. (2014). Court Rules Jobbik Cannot Be Called "Far-right". Derived from: https:// euobserver.com/eu-elections/124509. 